
\title{
$\begin{array}{ll}\text { Research Square } & \begin{array}{l}\text { Preprints are preliminary reports that have not undergone peer review. } \\ \text { They should not be considered conclusive, used to inform clinical practice, } \\ \text { or referenced by the media as validated information. }\end{array}\end{array}$
}

\section{Glycomyces salinus sp. nov., an Actinomycete Isolated From a Hypersaline Habitat}

Rui Li

Yunnan University

Gang-Qiang Jiang

Urumqi Customs Technology Center

Yun Wang

Life science and Technology School,Lingnan Normal University,Zhanjiang

\section{Yi-Guang Chen}

Jishou University

En-Min Zhou

Yunnan University

Shu-Kun Tang ( $\boldsymbol{\nabla}$ tangshukun@ynu.edu.cn )

Yunnan Institute of Microbiology, Yunnan University https://orcid.org/0000-0001-9141-6244

\section{Research Article}

Keywords: Glycomyces salinus sp. nov., Polyphasic taxonomy, Halophile, Actinobacteria

Posted Date: June 10th, 2021

DOI: https://doi.org/10.21203/rs.3.rs-591847/v1

License: (c) (i) This work is licensed under a Creative Commons Attribution 4.0 International License. Read Full License

Version of Record: A version of this preprint was published at Archives of Microbiology on August 9th, 2021. See the published version at https://doi.org/10.1007/s00203-021-02510-4. 


\section{Abstract}

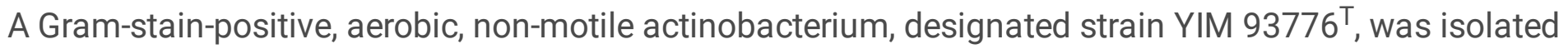
from a saline sediment sample collected from Aiding Lake in Xinjiang Uygur Autonomous Region, Northwest China. Phylogenetic analysis based on the 16S rRNA gene sequences showed that strain YIM $93776^{\top}$ was affiliated to the genus Glycomyces, and was closely related to Glycomyces albus TRM $49136^{\top}$ (97.6 \% sequence similarity), Glycomyces lacisalsi XHU 5089 ${ }^{\top}(97.0 \%)$ and Glycomyces anabasis EGI $6500139^{\top}(96.2 \%)$. The cell wall contained meso-diaminopimelic acid and the whole-cell hydrolysates sugars were galactose, mannose, arabinase, glucose and ribose. The predominant menaquinones were MK-9 $\left(\mathrm{H}_{4}\right)$ and MK-10 $\left(\mathrm{H}_{4}\right)$. Diphosphatidylglycerol, phosphatidylglycerol, phosphatidylinositol, two phosphatidylglyceride, two unidentified phospholipids and two unidentified polar lipids were detected in the polar lipid extracts. Major fatty acids were anteiso- $C_{17: 0}$, iso- $C_{15: 0}$, iso$C_{16: 0}$, anteiso- $C_{15: 0}$ and anteiso $C_{17: 1} A$. The draft genome sequence of strain YIM 93776 ${ }^{\top}$ was $5.37 \mathrm{Mbp}$ in size with $69.5 \mathrm{~mol} \%$ DNA G+C content. On the basis of morphological, chemotaxonomic and phylogenetic evidence, strain YIM $93776^{\top}$ therefore represents a novel species, for which the name

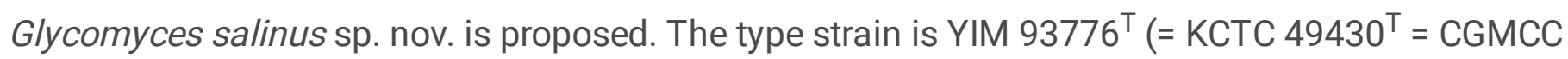
$\left.4.7685^{\top}\right)$.

\section{Introduction}

The genus Glycomyces was initially proposed by Labeda et al. (1985) with Glycomyces harbinensis as the type species, and the description was later emended by Labeda and Kroppenstedt (2004). Strains belonging to the genus Glycomyces are Gram-stain-positive actinobacteria that form an extensively branched vegetative mycelium and aerial hyphae on certain growth media. These bacteria have a type II cell-wall composition (meso-diaminopimelicacid and glycine), whole-cell sugar pattern D (xylose, ribose, mannose, galactose and arabinose), and type PI phospholipid pattern with significant amounts of diphosphatidylglycerol. Most members of Glycomyces strains are isolated from soil, saline environments, and traditional Chinese medicinal plants tissues. At the time of writing, there are 26 validly published names in this genus (https://lpsn.dsmz.de/genus/glycomyces) with the latest described Glycomyces terrestris by Li et al. (2021), Glycomyces albidus by Qian et al. (2020), Glycomyces buryatensis by Nikitina et al. (2020), Glycomyces xiaoerkulensis by Wang et al. (2018), Glycomyces sediminimaris by Mohammadipanah et al. (2018), Glycomyces paridis by Fang et al. (2018), Glycomyces dulcitolivorans by Mu et al. (2018), and Glycomyces anabasis by Zhang et al. (2018). In the present study, we isolated a halophilic actinobacteria designated as strain YIM $93776^{\top}$ that was associated with genus Glycomyces. Based on the results of phylogenetic, chemotaxonomic and physiological characterization of strain YIM $93776^{\top}$, we propose the strain YIM $93776^{\top}$ represents a novel Glycomyces species.

\section{Methods And Materials}

\section{Bacterial isolation and cultivation}


Strain YIM $93776^{\top}$ was isolated by using standard serial dilution plating technique from a hyper-saline sediment sample obtained from Aiding Lake (GPS, 42 68'66"N, 89 33'07"E) in Xinjiang Uygur

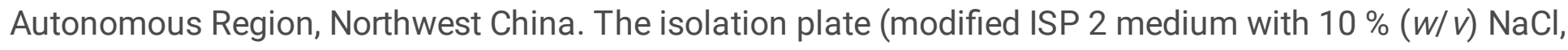
Shirling and Gottlieb, 1966) were incubated at $37^{\circ} \mathrm{C}$ for 2 weeks. Presumptive actinomycete colonies were picked and re-streaked $>3$ times to obtain axenic cultures. Strain YIM $93776^{\top}$ was selected among other strains for further characterization using polyphasic taxonomy based on the phylogenetic profiles of the 16S rRNA gene sequence. Pure cultures of strain YIM $93776^{\top}$ were routinely cultured and maintained on ISP 2 medium containing $10 \%(\mathrm{w} / \mathrm{v}) \mathrm{NaCl}$ at $4^{\circ} \mathrm{C}$ and as glycerol suspensions $(20 \%, \mathrm{v} / \mathrm{v})$ at $-80^{\circ} \mathrm{C}$. Strain YIM $93776^{\top}$ was deposited in China General Microbiological Culture Collection Center (CGMCC) and Korean Collection for Type Cultures (KCTC) with the number CGMCC $4.7685^{\top}$ and KCTC $49430^{\top}$, respectively.

\section{Phylogenetic and genomic analyses}

Extraction of genomic DNA, PCR amplification and sequencing of the 16S rRNA gene were carried out as described previously (Feng et al. 2020). The almost-complete 16S rRNA gene sequence (1445 bp) was checked manually and submitted to the GenBank database. Pairwise similarity values between strain YIM $93776^{\top}$ and its closely related type strains were calculated via the EzBioCloud server (https://www.ezbiocloud.net) (Yoon et al. 2017). The 16S rRNA gene sequence was aligned with multiple sequences obtained from the GenBank/EMBL/DDBJ databases using CLUSTAL X (Thompson et al. 1997). Phylogenetic trees with gaps completely deleted were reconstructed based on the neighbourjoining (NJ) (Saitou et al. 1987), maximum-likelihood (ML) (Felsenstein et al. 1981) and maximumparsimony (MP) (Fitch et al. 1971) algorithms, by using the MEGA version 7.0 software package (Kumar et al. 2016). Bootstrap analysis with 1000 replicates was applied to assess confidence levels of the branches (Felsenstein, 1985). Kimura's two-parameter model (Kimura, 1980) was used to calculate evolutionary distance matrices for the NJ methods. ML was calculated using the general time-reversible model with gamma-distribution with invariant sites $(G+I)$.

The draft genome of strain YIM 93776 ${ }^{\top}$ was sequenced using PacBio and Illumina Hiseq 2000 sequencers at Shanghai Majorbio Bio-pharm Technology Co., Ltd (Shanghai, China). SOAPdenovo software (version 2.04) was employed to assemble paired-end reads ( $\mathrm{Li}$ et al. 2010). The $\mathrm{G}+\mathrm{C}$ contents (mole percent) were calculated from the genome sequences. To assess relationships between the strain YIM $93776^{\top}$ and sequenced related strains, we performed a phylogenomic analysis and constructed the evolutionary tree based on orthologous genes using the supermatrix method (Zhi et al. 2017).

\section{Phenotypic, physiological and biochemical characteristics}

Cultural characteristics were determined after 7 and 14 days of incubation at $37^{\circ} \mathrm{C}$ on different agar media (ISP 2, ISP 3, ISP 4 and ISP 5, Czapek's agar, PDA, and NA media) with $10 \%$ (w/v) NaCl concentration. Growth at different temperatures $\left(4,10,15,20,25,28,30,35,37,40,45,50\right.$ and $55^{\circ} \mathrm{C}$ )

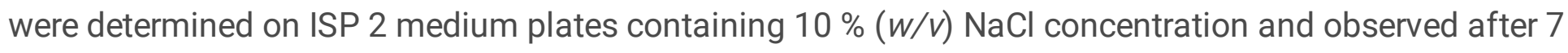


and 14 days. Salt tolerance $\left(0-30 \%, \mathrm{w} / \mathrm{v}, \mathrm{NaCl}\right.$ at $5 \%$ intervals) was examined at $37{ }^{\circ} \mathrm{C}$ on ISP 2 agar medium for 14 days. A series of $\mathrm{pH}$ conditions (4.0-11.0, at 0.5 intervals) using the buffer system described by Xu et al. (2005). Growth was assessed by monitoring turbidity as OD660 by using a spectroscopic method (Lambda 35 UV/Vis Spectrometer; PerkinElmer). After incubation on Czapek's agar (containing $10 \%, \mathrm{w} / \mathrm{v} \mathrm{NaCl}$ ) at $37^{\circ} \mathrm{C}$ for 7 days and 28 days, morphological properties and spore motility were examined by means of a light microscope (DM2000, Leica) and a scanning electron microscope (XL30 ESEM-TMP, Philips-FEI). Gram staining was carried out by using the standard Gram reaction and was confirmed by using the $\mathrm{KOH}$ lysis test method. Carbon source utilization for growth was carried out on ISP 9 medium containing $10 \%(w / v) ~ N a C l$ as described by Shirling and Gottlieb (1966). Nitrogen source utilization tests were carried out as described by Gordon et al. (1974). Catalase activity was detected based on bubble formation in $3 \%(\mathrm{v} / \mathrm{v}) \mathrm{H}_{2} \mathrm{O}_{2}$ solution. Oxidase activity was detected by the oxidation of tetramethyl-p-phenylenediamine. Hydrolysis of starch, casein, gelatin, cellulose and Tweens 20,40 , and 80 , nitrate reduction, urease activity, coagulation and peptonization of milk, melanin and $\mathrm{H}_{2} \mathrm{~S}$ production were determined as described by Smibert and Krieg (1994). Other enzymatic activities of strain YIM 93776 ${ }^{\top}$ were analyzed using API 20NE and API ZYM kits (bioMérieux, France) according to the manufacturer's instructions. The acid production from carbohydrates was determined using the API $50 \mathrm{CH}$ system (bioMérieux, France) according to the manufacturer's instructions.

\section{Chemotaxonomic characteristics}

Biomass used for chemotaxonomic studies except fatty acid was obtained from cultures grown on ISP2 plate containing $10 \%(w / v) ~ N a C l$ for 14 days at $37^{\circ} \mathrm{C}$. The diagnostic isomers of diaminopimelic acid were determined by HPLC according to methods used by Tang et al. (2009) and using TLC to verify it (Hasegawa et al.1983, Lechevalier et al.1970). The whole-cell sugar pattern and peptidoglycan amino acids were detected by HPLC according to methods used by Tang et al. (2009). The respiratory quinones were isolated using the method of Collins et al. (1977) and analysed by HPLC (Agilent Technologies 1260 Infinity) (Groth et al.1996). Polar lipids were extracted and then separated by using two dimensional TLC and identified using previously described procedures (Minnikin et al.1984; Hasegawa et al.1983).

Molybdophosphoric acid, molybdenum blue, ninhydrin and $\alpha$-naphthol were used for the detection of total polar lipids, phospholipids, aminolipids and glycolipids, respectively. For cellular fatty acid analysis, strain YIM $93776^{\top}$ was grown on tryptic soya agar (TSA; Difco) with $10 \%(w / v) ~ N a C l$ at $37^{\circ} \mathrm{C}$ and harvested after 7 days. Fatty acid methyl esters were extracted, methylated and analysed by using the Microbial Identification System (Sherlock version 6.1; MIDI database: TSBA6) according to the manufacturer's instructions (Sasser et al.1990).

\section{Results And Discussion}

\section{Molecular phylogenetic analysis}

16S rRNA gene sequence analysis showed that strain YIM $93776^{\top}$ was related most closely to the type strains of Glycomyces albus (97.6\% similarity), Glycomyces lacisalsi (97.0\% similarity), Glycomyces 
anabasis (96.2 \% similarity). Lower levels of 16S rRNA gene sequence similarity (92.0-95.1\%) were found with the type strains of all other type species within the genus Glycomyces. These values were below the $98.7 \%$ cutoff point recommended for recognition of genomic species which need not to do DNA-DNA hybridization experiments (Jongsik et al. 2018). The neighbour-joining phylogenetic tree based on $16 \mathrm{~S}$ rRNA gene sequences indicated strain YIM $93776^{\top}$ formed a branch distinct from those of their related species (Fig. 1). This relationship was supported by a high level of bootstrap support. The topologies of phylogenetic trees constructed with the maximum-likelihood and maximum-parsimony algorithms were similar to that of the tree reconstructed by neighbour-joining analysis (Supplementary information Fig. $\mathrm{S} 1, \mathrm{~S} 2)$. The draft genome of strain YIM $93776^{\top}$ is $5.36 \mathrm{Mbp}$ long with a $69.5 \mathrm{~mol} \% \mathrm{G}+\mathrm{C}$ content. The phylogeomic tree also supported that strain YIM $93776^{\top}$ formed a distinct phylogenetic lineage within the genus Glycomyces (Supplementary information Fig. S3). These results indicated that strain YIM $93776^{\top}$ should be considered as a separate novel species.

\section{Phenotypic, physiological and biochemical characteristics}

Growth of strain YIM $93776^{\top}$ was observed at pH 5.5-11 (optimum 8) and in the presence of $5-13 \%$ $(\mathrm{w} / \mathrm{v}) \mathrm{NaCl}$. The temperature range for growth was $25-45^{\circ} \mathrm{C}$, with optimum growth at $37^{\circ} \mathrm{C}$. Strain YIM $93776^{\top}$ grew well on Czapek's agar and NA and moderately well on ISP 2, ISP 3, ISP 4, ISP 5 and PDA media $(10 \%, \mathrm{w} / \mathrm{v} \mathrm{NaCl})$. White substrate mycelia developed well on the above media. Aerial mycelium was white and abundantly produced on Czapek's and NA media, but absent on ISP 2, ISP 3, ISP 4 and ISP 5 media. Diffusible pigments or melanin were not observed on any test media. When strain YIM $93776^{\top}$ grown on Czapek's agar containing $10 \%(w / v) ~ N a C l$, fragmented substrate were observated on 7 days and aerial hyphae with fragmentation was detected on 28 days. The mobility of spores was not observed (Supplementary information Fig. S4). The detailed physiological characteristics of strain YIM $93776^{\top}$ are presented in Table 1, Table S1 and in the species description.

\section{Chemotaxonomic characteristics}

Strains YIM $93776^{\top}$ contained meso-diaminopimelic acid as the cell-wall diamino acid, which was consistent with membership of the genus Glycomyces. The whole-cell sugar patterns of strain YIM $93776^{\top}$ contained galactose, mannose, arabinase, glucose and ribose, which differed slightly from reports for recognized species of the genus Glycomyces (Labeda et al. 2004) in that the novel strain did not contain xylose. The predominant menaquinones were MK-9 $\left(\mathrm{H}_{4}\right)(50.3 \%)$ and MK-10 $\left(\mathrm{H}_{4}\right)(41.81 \%)$. Major fatty acids (> $10 \%$ ) of strain YIM $93776^{\top}$ were anteiso- $\mathrm{C}_{17: 0}$, iso- $\mathrm{C}_{15: 0}$, iso- $\mathrm{C}_{16: 0}$, anteiso- $\mathrm{C}_{15: 0}$, and anteiso $C_{17: 1} A$ (Supplementary information Table S2). The polar lipids profiles of strain YIM $93776^{\top}$ were diphosphatidylglycerol, phosphatidylglycerol, phosphatidylinositol, two phosphatidylglyceride, two unidentified phospholipids and two unidentified polar lipids (Supplementary information Fig. S5).

The phylogenetic data indicate that strain YIM $93776^{\top}$ represents a novel species in the genus Glycomyces. In addition, the morphological and chemotaxonomic characteristics clearly differentiate 
strain YIM $93776^{\top}$ from other related species of genus Glycomyces (Table 1). Strain YIM $93776^{\top}$ contained glucose, mannose, ribose, arabinose and galactose, but no xylose which Glycomyces albus does contain. In conclusion, on the basis of phylogenetic analysis, chemotaxonomic data and phenotypic traits, strain YIM $93776^{\top}$ is considered to represent a novel species in the genus Glycomyces, for which the name Glycomyces salinus sp. nov. is proposed.

\section{Description of Glycomyces salinus sp. nov.}

Glycomyces salinus (sa.li'nus. N.L. masc. adj. salinus salted, saline)

Aerobic, Gram-stain-positive actinomycete. Aerial mycelium develops well on Czapek's and NA media. Soluble pigments are not produced. Aerial mycelium is long and fragmented with no branches. Aesculin, Tweens 20 and 40 were hydrolysed, but Tweens 80 , starch and cellulose was not. Nitrate reduction, milk coagulation and peptonization, $\mathrm{H}_{2} \mathrm{~S}$ production, gelatin liquefaction and urease are negative.

Temperature range for growth is $25-45^{\circ} \mathrm{C}$ with the optimum at $37^{\circ} \mathrm{C}$; $\mathrm{pH}$ range for growth is $\mathrm{pH} 5.5-11.0$ and the optimum is $\mathrm{pH} 8 ; \mathrm{NaCl}$ tolerance range for growth is $5-13 \%(\mathrm{w} / \mathrm{v}) \mathrm{NaCl}$ and the optimum is $10 \%$ $(\mathrm{w} / \mathrm{v}) \mathrm{NaCl}$. $D$-mannitol, maltitol, maltose, $\alpha$-lactose, fructose and $\alpha$-D-glucose are utilized as sole carbon sources. $L$-phenylalanine, adenine, glycine, $L$-methionine, $L$-threonine, aspartic acid, $L$-lysine, arginine, $L$ tyrosine, $L$-asparagine and alanine are utilized as sole nitrogen sources. Results from API $50 \mathrm{CH}$ tests showed that acids produced from erythritol, $D$-arabinose, $L$-arabinose, $D$-ribose, $D$-xylose, $D$-galactose, $D$ glucose, fructose, $D$-mannose, $L$-rhamnose, inositol, arbutin, esculin ferric citrate, salicin, $D$-cellobiose, $D$ maltose, $D$-saccharose, $D$-trehalose, $D$-melezitose, Amidon, glycogen, $D$-tagatose, $D$-fucose, $L$-fucose, potassium 5-ketogluconate. For enzyme activities (API ZYM system), it is positive for $a$-glucosidase, naphthol-AS-BI-phosphohydrolase. Contains meso-diaminopimelic acid as the diamino acid. The wholecell sugar pattern consists of galactose, mannose, arabinase, glucose and ribose. The polar lipids pattern consists of diphosphatidylglycerol, phosphatidylglycerol, phosphatidylinositol, two phosphatidylglyceride, two unidentified phospholipids and two unidentified polar. The predominant menaquinones are MK-9 $\left(\mathrm{H}_{4}\right)$ and MK-10 $\left(\mathrm{H}_{4}\right)$. Major cellular fatty acids are anteiso- $\mathrm{C}_{17: 0}$, iso- $\mathrm{C}_{15: 0}$, iso- $\mathrm{C}_{16: 0}$, anteiso- $\mathrm{C}_{15: 0}$, and anteiso $\mathrm{C}_{17: 1} \mathrm{~A}$.

The type strain, YIM $93776^{\top}\left(\right.$ KCTC $49430^{\top}=$ CGMCC $\left.4.7685^{\top}\right)$, was isolated from a hyper-saline sediment sample obtained from Aiding Lake in Xinjiang Uygur Autonomous Region, Northwest China. The DNA G + C content of the type strain is $69.5 \mathrm{~mol} \%$.

\section{Abbreviations}

CA, Czapek's agar; PDA, potato dextrose agar; NA, nutrient agar media; ISP 3, Oat agar; ISP 5, glycerol/asparagine agar; ISP 4, inorganic salts-starch agar; ISP2, yeast extract-malt extract agar; DPG, diphosphatidylglycerol; PG, phosphatidylglycerol; PGL, Phosphatidylglyceride; UL, unidentified polar lipids; PI, phosphatidylinositol; PL, unidentified phospholipids 
The NCBI GenBank accession number for the $16 \mathrm{~S}$ rRNA gene sequence of strain YIM $93776^{\top}$ is MW380665. The draft whole genome sequence for strain YIM $93776^{\top}$ has been deposited at DDBJ/ENA/GenBank under accession number GCA_016428645.1.

\section{Declarations}

\section{Author contributions}

$\mathrm{RL}$ and E-MZ carried out the data analysis and wrote the manuscript. $\mathrm{RL}, \mathrm{YW}$ and $\mathrm{Y}-\mathrm{GC}$ performed the experiments. G-QJ provided the samples. E-MZ and S-KT supervised the project. All the authors discussed the results and contributed to the final manuscript.

\section{Conflict of interest statement}

The authors declare that the research was conducted in the absence of any commercial or financial relationships that could be construed as a potential conflict of interest.

\section{Acknowledgements}

This study was supported by the National Natural Science Foundation of China (31760003 and 31970122), the Natural Science Foundation of Yunnan Province (202001BB050040) and Major Science and Technology Projects of Yunnan Province (Digitalization, development, and application of biotic resource 202002AA100007).

\section{References}

1. Collins MD, Pirouz T, Goodfellow M, Minnikin DE (1977) Distribution of menaquinones in actinomycetes and corynebacteria. J Gen Microbiol 100 (2): 221-230.

2. Chun J, Oren A, Ventosa A, Christensen H, Arahal DR, da Costa MS, Rooney AP, Yi H, Xu XW, De Meyer S, Trujillo ME (2018) Proposed minimal standards for the use of genome data for the taxonomy of prokaryotes. Int J Syst Evol Microbiol 68 (1):461-466.

3. Cowan ST, Steel KJ (1965) Manual for the Identification of Medical Bacteria. London: Cambridge University Press.

4. Fang XM, Bai JL, Su J, Zhao LL, Liu HY, Ma BP, Zhang YQ, Yu LY (2018) Glycomyces paridis sp. nov., isolated from the medicinal plant Paris polyphylla. Int J Syst Evol Microbiol 68 (5):1578-1583.

5. Felsenstein J (1981) Evolutionary trees from DNA sequences: a maximum likelihood approach. J Mol Evol 17 (6):368-376.

6. Felsenstein J (1985) Confidence limits on phylogenies: an approach using the bootstrap. Evolution 39 (4):783-791.

7. Feng YZ, Chunyu WX, Liang R, Hahnke RL, Schumann P, Zhao YR, Gao S, Yin M, Ji Y, Sun L, Zhi XY, Tang SK (2020) Vallicoccus soli gen. nov., sp. nov., a novel actinobacterium isolated from soil, and 
description of Vallicoccaceae fam. nov., Motilibacterales ord. nov. Antonie Van Leeuwenhoek 113 (12):2155-2165.

8. Fitch WM (1971) Toward defining the course of evolution: minimum change for a specific tree topology. Syst Zool 20 (4):406-416.

9. Gordon RE, Barnett DA, Handerhan JE, Pang CH-N (1974) Nocardia coeliaca, Nocardia autotrophica, and the nocardin strain. Int J Syst Bacteriol 24 (1):54-63.

10. Gregersen $\mathrm{T}$ (1978) Rapid method for distinction of gram-negative from gram-positive bacteria. Eur J Appl Microbiol Biotechnol 5 (2): 123-127.

11. Groth I, Schumann P, Weiss N, Martin K, Rainey FA (1996) Agrococcus jenensis gen. nov., sp. nov., a new genus of actinomycetes with diaminobutyric acid in the cell wall. Int J Syst Bacteriol 46 (1):234-239.

12. Guan TW, Wang PH, Tian L, Tang SK, Xiang HP (2016) Glycomyces lacisalsi sp. nov., an actinomycete isolated from a hypersaline habitat. Int J Syst Evol Microbiol 66 (12): 5366-5370.

13. Han XX, Luo XX, Zhang LL (2014) Glycomyces fuscus sp. nov. and Glycomyces albus sp. nov., actinomycetes isolated from a hypersaline habitat. Int J Syst Evol Microbiol 64 (Pt 7): 2437-2441.

14. Hasegawa T, Takizawa M, Tanida S (1983) A rapid analysis for chemical grouping of aerobic actinomycetes. J Gen Appl Microbiol 29(4):319-322.

15. Kimura M (1980) A simple method for estimating evolutionary rates of base substitutions through comparative studies of nucleotide sequences. J Mol Evol 16 (2):111-120.

16. Kumar S, Stecher G, Tamura K (2016) MEGA7: molecular evolutionary genetics analysis version 7.0 for bigger datasets. Mol Biol Evol 33 (7):1870-1874.

17. Labeda DP, Testa RT, Lechevalier MP, Lechevalier HA (1985) Glycomyces, a new genus of the Actinomycetales. Int J Syst Bacteriol 35 (4):417-421.

18. Labeda DP, Kroppenstedt RM (2004) Emended description of the genus Glycomyces and description of Glycomyces algeriensis sp. nov., Glycomyces arizonensis sp. nov. and Glycomyces lechevalierae sp. nov. Int J Syst Evol Microbiol 54 (6), 2343-2346.

19. Lechevalier MP, Lechevalier HA (1970) Chemical composition as a criterion in the classification of aerobic actinomycetes. Int J Syst Bacteriol 20 (4):435-443.

20. Li R, Zhu H, Ruan J, Qian W, Fang X, Shi Z, Li Y, Li S, Shan G, Kristiansen K (2010) De novo assembly of human genomes with massively parallel short read sequencing. Genome Res 20 (2):265-272.

21. Li Q, Li G, Lang L, An D, Jiang C, Jiang Y (2021) Glycomyces terrestris sp. nov., isolated from extremely arid soil from Yuanmou Earth Forest. Int J Syst Evol Microbiol 71 (1):004580.

22. Minnikin DE, O'Donnell AG, Goodfellow M, Alderson G, Athalye M et al (1984) An integrated procedure for the extraction of bacterial isoprenoid quinones and polar lipids. J Microbiol Methods 2 (5):233241.

23. Mohammadipanah F, Atasayar E, Heidarian S, Wink J (2018) Glycomyces sediminimaris sp. nov., a new species of actinobacteria isolated from marine sediment. Int J Syst Evol Microbiol 68 (7):2357- 
2363.

24. Mu S, Sun T, Li Y, Jiang S, Guo X, Wang X, Zhao J, Xiang W (2018) Glycomyces dulcitolivorans sp. nov., isolated from rhizosphere soil of wheat (Triticum aestivum L.). Int J Syst Evol Microbiol 68 (9):3034-3039.

25. Nikitina E, Liu SW, Li FN, Buyantueva L, Abidueva E, Sun CH (2020) Glycomyces buryatensis sp. nov., an actinobacterium isolated from steppe soil. Int J Syst Evol Microbiol 70 (2):1356-1363.

26. Qian L, Duan L, Lin J, Yang Y, Song J, Wang X, Zhao J, Xiang W (2020) Glycomyces albidus sp. nov., a novel actinobacterium isolated from rhizosphere soil of wheat (Triticum aestivum L.). Int J Syst Evol Microbiol 70 (5):3096-3104.

27. Saitou N, Nei M (1987) The neighbor-joining method: a new method for reconstructing phylogenetic trees. Mol Biol Evol 4 (4): 406-425.

28. Sasser M (1990) Identification of bacteria by gas chromatography of cellular fatty acids. USFCC Newsl 20:16.

29. Shirling EB, Gottlieb D (1966) Methods for characterization of Streptomyces species. Int J Syst Bacteriol 16 (3):313-340.

30. Smibert RM, Krieg NR (1994) Phenotypic characterization. In Methods for General and Molecular Bacteriology, pp. 607-654. Edited by P. Gerhardt, Murray RGE, Wood WA \& Krieg NR. Washington, D.C.: American Society for Microbiology.

31. Tang SK, Wang Y, Chen Y, Lou K, Cao LL et al (2009) Zhihengliuella alba sp. nov., and emended description of the genus Zhihengliuella. Int J Syst Evol Microbiol 59 (8):2025-2032.

32. Thompson JD, Gibson TJ, Plewniak F, Jeanmougin F, Higgins DG (1997) The CLUSTAL_X windows interface: flexible strategies for multiple sequence alignment aided by quality analysis tools. Nucleic Acids Res 25 (24):4876-4882.

33. Wang Y, Luo XX, Xia ZF, Wan CX, Alim A, Zhang LL (2018) Glycomyces xiaoerkulensis sp. nov., isolated from Xiaoerkule lake in Xinjiang, China. Int J Syst Evol Microbiol 68 (9):2722-2726.

34. Williams ST, Goodfellow M, Alderson G, Wellington EM, Sneath PH et al (1983) Numerical classification of Streptomyces and related genera. J Gen Microbiol 129 (6):1743-1813.

35. Xu P, Li WJ, Tang SK, Zhang YQ, Chen GZ et al (2005) Naxibacter alkalitolerans gen. nov., sp. nov., a novel member of the family 'Oxalobacteraceae' isolated from China. Int J Syst Evol Microbiol 55 (3):1149-1153.

36. Yoon SH, Ha SM, Kwon S, Lim J, Kim Y et al (2017) Introducing EzBioCloud: a taxonomically united database of 16S rRNA gene sequences and whole-genome assemblies. Int J Syst Evol Microbiol 67 (5):1613-1617.

37. Zhang YG, Wang HF, Alkhalifah DHM, Xiao M, Zhou XK, Liu YH, Hozzein WN, Li WJ (2018) Glycomyces anabasis sp. nov., a novel endophytic actinobacterium isolated from roots of Anabasis aphylla L. Int J Syst Evol Microbiol 68 (4):1285-1290. 
38. Zhi X-Y, Jiang Z, Yang L-L, Huang Y (2017) The underlying mechanisms of genetic innovation and speciation in the family Corynebacteriaceae: a phylogenomics approach. Mol Phylogen Evol 107:246-255.

\section{Table}


Table 1

Differential characteristics of strain YIM $93776^{\top}$ and other phylogenetically closely related species.

\section{Characteristic}

1

2

Growth:

Temperature $\quad 25-45(37)$

range

(optimum, ${ }^{\circ} \mathrm{C}$ )

$\mathrm{NaCl}$ range

(optimum, \%)

$\mathrm{pH}$ range

(optimum)

Nitrate

reduction

Urease

Oxidase

Hydrolysis of:

Starch

Cellulose

Tweens 80

Utilization of:

Arabinose

Xylose

Raffinose

D-galactose

Maltose

Sucrose

Maltitol

a-lactose

a-D-glucose

Cellobiose

D-fructose

$$
\text { 5-13 (10) }
$$

5.5-11 (8)

$+$

$+$

$+$

$+$

$+$

$+$

$+$

$-$

$-$

$+$
$25-40(30)$

$20-50(30-$
$35)$

$15-40(30)$

3

4

$\begin{array}{lll}0-13(5-7) & 0-9(1-3) & 0-10(4-6) \\ 6-14(8-9) & 6-12(7-8) & 6-10(7-8)\end{array}$

_\#

NR

$+$

$+$

$+$

$+$

NR

$+$

NR

- NR

- NR

$+$

- +

$+$ 


\begin{tabular}{|c|c|c|c|c|}
\hline Characteristic & 1 & 2 & 3 & 4 \\
\hline Glycerol & - & + & - & - \\
\hline Inositol & - & + & + & - \\
\hline D-mannose & - & - & + & - \\
\hline Melibiose & - & - & + & - \\
\hline L-rhamnose & - & + & - & - \\
\hline D-ribose & - & + & - & - \\
\hline D-sorbitol & - & + & - & - \\
\hline $\begin{array}{l}\text { Whole-cell } \\
\text { sugars }\end{array}$ & $\begin{array}{l}\text { galactose, mannose, } \\
\text { arabinase, glucose, } \\
\text { ribose }\end{array}$ & $\begin{array}{l}\text { xylose, ribose, } \\
\text { arabinose }\end{array}$ & $\begin{array}{l}\text { glucose, } \\
\text { galactose }\end{array}$ & $\begin{array}{l}\text { glucose, } \\
\text { mannose, ribose, } \\
\text { galactose, xylose }\end{array}$ \\
\hline Polar lipids & $\begin{array}{l}\text { DPG, PL, PGL, PG, PI, } \\
\text { UL }\end{array}$ & $\begin{array}{l}\text { PG, DPG, PI, PIM, } \\
\text { GL, PGL }\end{array}$ & $\begin{array}{l}\text { DPG, PG, PI, } \\
\text { PL, GL" }\end{array}$ & $\begin{array}{l}\text { PG, DPG, PI, PIM, } \\
\text { GL, PL, ULs }\end{array}$ \\
\hline $\begin{array}{l}\text { Major } \\
\text { menaquinones }\end{array}$ & MK-9 $\left(\mathrm{H}_{4}\right)$, MK-10 $\left(\mathrm{H}_{4}\right)$ & $\begin{array}{l}\text { MK-9 }\left(\mathrm{H}_{4}\right), \text { MK- } \\
9\left(\mathrm{H}_{6}\right)\end{array}$ & $\begin{array}{l}\text { MK-10 }\left(\mathrm{H}_{4}\right) \\
\text { MK-9 }\left(\mathrm{H}_{4}\right), \text { MK- } \\
\left.\text { 10( } \mathrm{H}_{2}\right), \text { MK-11 }\end{array}$ & $\begin{array}{l}\text { MK-11, MK- } \\
11\left(\mathrm{H}_{2}\right)\end{array}$ \\
\hline $\begin{array}{l}\text { Major fatty } \\
\text { acids (> } 10 \%)\end{array}$ & $\begin{array}{l}\text { anteiso- } C_{17: 0} \text {, iso- } C_{15: 0} \\
\text { iso- } C_{16: 0} \text {, anteiso- } C_{15: 0} \\
\text { anteiso } C_{17: 1} A\end{array}$ & $\begin{array}{l}\text { anteiso- } \mathrm{C}_{17: 0}, \\
\text { anteiso- } \mathrm{C}_{15: 0} \\
\text { iso- } \mathrm{C}_{15: 0}, \text { iso- }_{16} \\
: 0\end{array}$ & $\begin{array}{l}\text { anteiso- } \mathrm{C}_{17: 0} \\
\text { anteiso- } \mathrm{C}_{15: 0} \\
\text { iso- }_{15: 0}\end{array}$ & $\begin{array}{l}\text { anteiso- } \mathrm{C}_{17: 0}, \\
\text { anteiso- } \mathrm{C}_{15: 0} \\
\text { iso- } \mathrm{C}_{15: 0}, \text { iso- }_{16} \text { : } \\
0\end{array}$ \\
\hline $\begin{array}{l}\text { DNA G + C } \\
\text { content } \\
\text { (mol\%) }\end{array}$ & 69.5 & 71.0 & 68.6 & 70.4 \\
\hline
\end{tabular}

\#Data was confirmed in this work.

Taxa:1. Strain YIM 93776'; 2. G. albus TRM 49136'\% (3) G. lacisalsi XHU 5089'\% (4) G. anabasis EGI $6500139^{\top}$. Data for strain YIM $93776^{\top}$ was taken from this study. Data for G. albus TRM $49136^{\top}, G$ lacisalsi XHU 5089 ${ }^{\top}$, and G. anabasis EGI $6500139^{\top}$ was taken from Han et al. (2014), Guan et al. (2016), and Zhang et al. (2018), respectively, unless otherwise specified. +, Positive; -, negative; NR: not reported. DPG, diphosphatidylglycerol; PG, phosphatidylglycerol; PGL, Phosphatidylglyceride; PI, phosphatidylinositol; PE, phosphatidylethanolamine; PL, phospholipids; GL, unidentified glycolipid; PIM, phosphatidylinositol mannoside; UL, unidentified polar lipid.

\section{Figures}




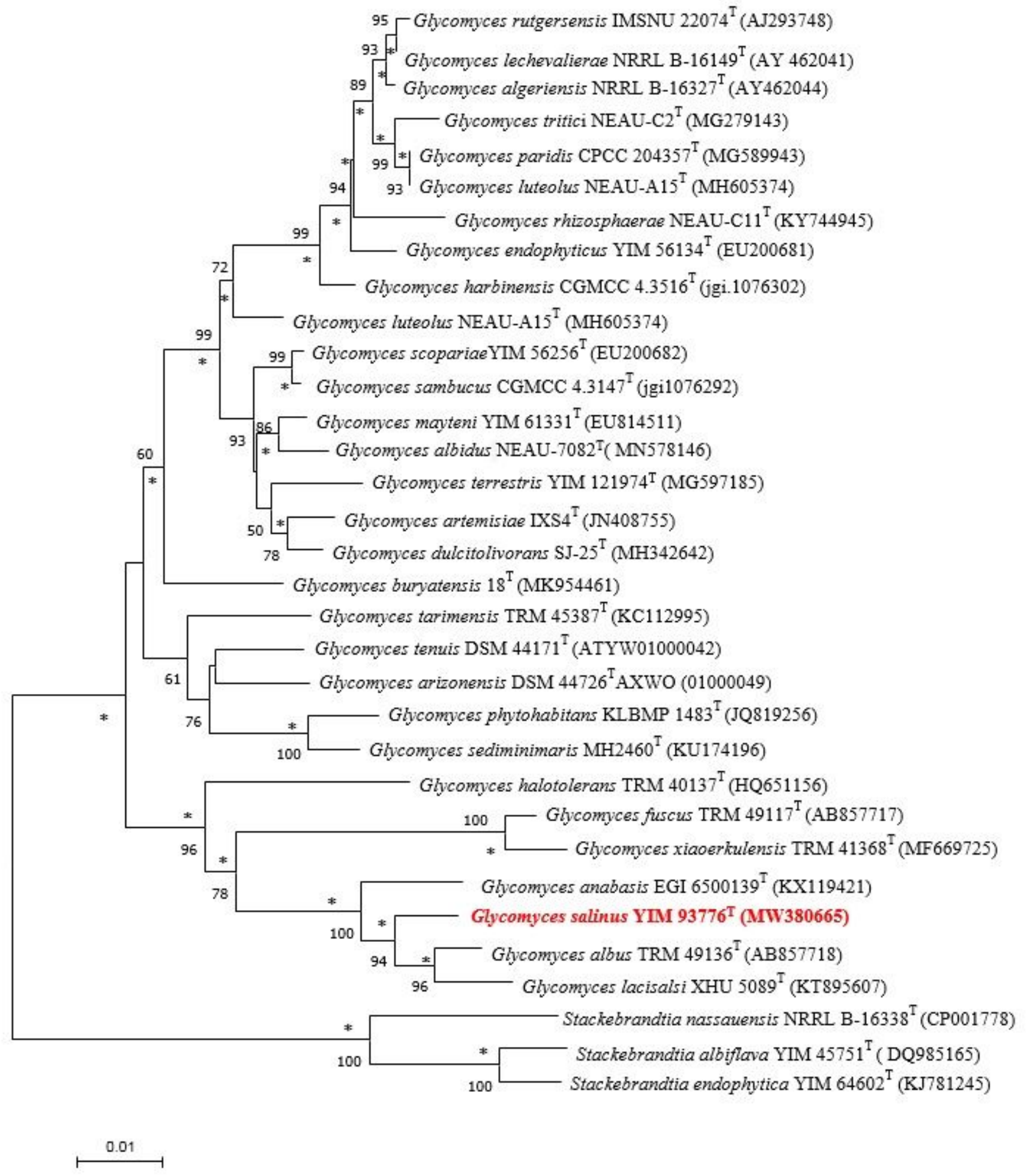

\section{Figure 1}

Neighbour-joining tree based on 16S rRNA gene sequences showing the position of strain YIM 93776T within the genus Glycomyces. Sequences of Stackebrandtia nassauensis NRRL B-16338T, Stackebrandtia albiflava YIM 45751T and Stackebrandtia endophytica YIM 64602T were used as outgroups. Bootstrap values (based on 1000 replications) greater than $50 \%$ are given at branching 
points. Asterisks denote nodes that were also recovered using the maximum-likelihood and maximumparsimony methods. Bar: one substitution per 100 nucleotide position.

\section{Supplementary Files}

This is a list of supplementary files associated with this preprint. Click to download.

- Supplementarymaterials.docx 